\title{
Obituary
}

\section{Alan Richard Tammadge 9 July 1921 - 25 Feb 2016}

Alan Tammadge, a Past President and Honorary Member of the Mathematical Association, was an influential figure in the mathematics curriculum reforms of the 1960s and later an outstanding Headmaster.

Alan studied at Bromley County School before moving to Dulwich College. On leaving there, in 1940, he joined the Royal Navy in which he served until 1947 when he resigned his commission and went up to Emmanuel College, Cambridge to study mathematics. After graduating in 1950, the same year in which he married Rosemary Anne Broadribb, he was appointed a lecturer at the Royal Military Academy, Sandhurst. While at Sandhurst, he rejoined the Mathematical Association, was in at the founding of the Association for Teaching Aids in Mathematics (ATAM) (now the Association of Teachers of Mathematics), and became an examiner for the Cambridge Local Examinations Syndicate: three actions that were to have a great effect on his future career. It was the ATAM and a 1953 report from the MA on 'The use of Visual Methods in the Teaching of Mathematics' that made him realise that there was more to mathematics teaching than he had previously realised. This encouraged him to leave the 'plushy' world of Sandhurst, with its restricted mathematics syllabus, and become a teacher at his old school, Dulwich College.

His examining work was also having an important effect. He became unhappy about the syllabus: 'Euclidean geometry had been watered down to the absurd and only a small number of candidates attempted questions on this topic and they normally regurgitated a theorem and collapsed when it came to a rider'. The idea of syllabus revision took hold and was only strengthened through attendances at conferences such as that held at Southampton University in 1961 which led to the establishment of the School Mathematics Project (SMP). By that time he had already spent three years as Head of the Mathematics Department of Abingdon School. When the SMP was established in 1962 its prior aim was to develop a new syllabus for the then Olevel examination and, because of the composition of the early writing team who worked in independent schools with an intake at 13 years, the decision was taken to write only two pre-O-level books. Schools at which students entered at age 11, such as Abingdon School, were encouraged to use other books that had recently appeared in the first school years. This arrangement did not appeal to Alan and in a sabbatical term, at the beginning of 1963, he drew up a new 11-16 syllabus which would lead to the SMP O-level. This syllabus was adopted by the SMP and Alan, together with Brian Bolt and John Holding of Exeter School - and later other younger teachers, were asked to write the appropriate books. What resulted, SMP Books 1-5, was one of the most influential series ever to appear, in the sense that no series of specifically school books can have been translated into so many different languages. 
Alan then became an increasingly busy person as he was invited to speak at conferences and meetings not only throughout Britain but also overseas. For example, he toured US Summer Schools and visited Ceylon. His experience of both curriculum reform and examining took him to Nigeria to advise the newly created West African Examination Council and to South Africa where a new syllabus for schools was being formulated.

Soon his outstanding ability as a leader was recognised and in 1967 he was appointed Master of Magdalen College School, Oxford. In 1971 he moved from there to be Head of Sevenoaks School, a post he occupied until his retirement in 1981.

There was also work for the BBC including series for sixth forms, for adults and, in 1970, 'Square 2, a second start in mathematics'. In 1977, Phyllis Starr and he had their 'A Parents' Guide to Mathematics' published. The following year he became President of the MA. Because of the great part that both the MA and the ATM had played in his development, he had hopes of bringing the two Associations into closer union and a special three day meeting was held involving HMI, Cockcroft, along with members of the committee recently established under his chairmanship, and representatives from the two Associations. The report Alan subsequently presented included such items as, 'The morale of the profession needs to be bolstered ...' and that 'Teachers need time to think <: two areas of agreement that have grown ever more relevant. Unfortunately a stumbling block to the union of the two associations arose in the differing views concerning the degree of autonomy that should be given to teachers: a block which, regrettably, succeeding governments have removed.

Retirement from Sevenoaks School did not mean the abandonment of mathematics teaching for Alan, for from 1982-1994 he regularly participated in the Royal Institution Master Classes. Rosemary died on 26, March 2008, and regrettably by then his health had begun to deteriorate. Sadly he had to spend the last years of his life in a nursing home. He left two sons and a daughter.

Alan was fortunate to live at a time when he was able to make such great contributions to mathematics teaching and he certainly made the most of those opportunities. It is sad that so much that he fought for, and succeeded in doing, is denied today's teachers.

10.1017/mag.2016.114

GEOFFREY HOWSON

1 Chidden Holt, Valley Park, Chandlers Ford, Eastleigh SO53 4RJ 